\title{
Quotas: A Pathway of Political Empowerment?
}

\author{
Ana Alice Alcântara Costa
}

\begin{abstract}
Over the last 20 years, the problem of low levels of representation of women in political office has been mobilising women, and especially feminists, throughout the world. The adoption of quotas has become a much-used tool to address the challenge of increasing women's political representation, and as a route to enhancing women's political empowerment. In Latin America, many countries have adopted quota systems, but with widely varying effects. This article takes stock of Latin American experience and asks to what extent quota systems have served as a pathway of women into politics. Identifying challenges to implementation and factors that have contributed to their success or failure, the article seeks to explore lessons that can be learnt from this experience that can help contribute to strengthening mechanisms and processes that support the achievement of greater equality in a sphere in which women continue to be grossly under-represented.
\end{abstract}

\section{Introduction}

Over the last 20 years, the problem of low levels of representation of women in political office has been mobilising women, and especially feminists, throughout the world. This article reflects on the experience of Latin America, where the implementation of quota systems for women in a context of affirmative action policies has figured as a major goal in women's struggles for access to power structures. In some countries, notably Costa Rica and Argentina, the introduction of quotas has produced changes in the balance of power, with women reaching significant levels of participation in legislative bodies. However, many other Latin American countries have adopted quota systems with no such effects. Half a century since they gained the right to vote, Latin American women have come to recognise that, in practice, the right they fought for did not guarantee the right to be elected.

This article asks two main questions: To what extent have quota systems in Latin America served as a pathway of women's political empowerment? What lessons can be learnt from this experience? In doing so, it addresses the need to situate affirmative action strategies such as quotas within a wider field of interventions to support women's political candidature and to support women once they enter political office. Pathways into politics are not always pathways to power, and the article highlights some of the common obstacles that women encounter in their engagement with formal politics, as well as what can be done to address them.

\section{The struggle for suffrage and the democratic deficit}

The struggle for women's right to vote in Latin America started in the latter half of the nineteenth century. Yet it was not until the two first decades of the twentieth century that more concerted feminist mobilisation to claim voting rights appeared in most Latin American countries. Ecuador was the first country to give women the vote, in 1929. Brazil and Uruguay followed suit in 1932, with other countries following in the 1940s. Paraguay (1961) and Colombia (1964) were among the last. Gaining the right to vote was followed by intensive efforts to enlist women voters. As can be seen from Table 1, women are now in the majority in the electorate of most Latin American countries.

Up to the 1990s, women's participation in formal politics was occasional, scarce and limited. Women 


\begin{tabular}{|c|c|c|}
\hline Country & Year women gained the right to vote & Women in electorate (\%) \\
\hline Argentina & 1947 & 51.0 \\
\hline Bolivia & 1952 & 49.9 \\
\hline Brazil & 1932 & 51.8 \\
\hline Chile & 1949 & 52.4 \\
\hline Colombia & 1957 & 51.0 \\
\hline Costa Rica & 1949 & 50.0 \\
\hline Cuba & 1934 & n.a. \\
\hline El Salvador & 1939 & 54.1 \\
\hline Ecuador & 1929 & 50.5 \\
\hline Guatemala & 1945 & 45.8 \\
\hline Haiti & 1950 & n.a. \\
\hline Honduras & 1955 & 50.6 \\
\hline Mexico & 1953 & 51.9 \\
\hline Nicaragua & 1955 & 54.0 \\
\hline Panama & 1945 & 58.3 \\
\hline Paraguay & 1961 & 52.5 \\
\hline Peru & 1955 & 49.7 \\
\hline Dominican Republic & 1942 & 50.4 \\
\hline Uruguay & 1932 & 52.4 \\
\hline Venezuela & 1947 & 50.0 \\
\hline
\end{tabular}

were generally elected because they were the wives, daughters or sisters of well-known male politicians (Veneziani 2006; Costa 1998). Until now, only four women have been elected president of their countries by popular vote. Three out of these four women were perfect examples of the model of political ascension as family heritage. Violeta Chamorro (1990/7), in Nicaragua, was the widow of Pedro Chamorro, journalist and leader of the non-Sandinista movement opposing dictator Anastacio Somoza. In Panama, Mireya Moscoso (1999/2004) was elected president when she became the director of the Amulfista Party immediately after her husband Arnulfo Arias, who was elected President of Panama three times, died. More recently, Cristina Fernandez was elected President of Argentina. Although she was a lawyer, local representative, congresswoman, senator and had a political history of her own, she was a presidential candidate representing her husband's, Nestor Kirchner, continuality. The only woman to depart from this pattern was Michelle Bachelet, who was elected President of Chile in 2006. She is a doctor, ex-Minister of Health and Defence and her political history is one of autonomy and independence.

There has been a recent increase in the number of women in the executive, principally due to affirmative action. Llanos and Sample (2008) (see Table 2) show that the number of women in the executive in Latin America has risen from 8.4 per cent in 1996 to 24 per cent in 2007.

This expansion in the number of women in the executive has been strongest in countries 
Table 2 Women in the executive

\begin{tabular}{|c|c|c|}
\hline Country & Participation in ministry offices (\%) & Local elective power \\
\hline Argentina & 25.0 & 8.5 \\
\hline Bolivia & 30.0 & 4.6 \\
\hline Brazil & 14.3 & 7.5 \\
\hline Chile & 36.4 & 12.1 \\
\hline Colombia & 23.1 & 9.0 \\
\hline Costa Rica & 37.5 & 9.9 \\
\hline El Salvador & 15.4 & 8.0 \\
\hline Ecuador & 32.0 & 6.0 \\
\hline Guatemala & 25.0 & 2.4 \\
\hline Honduras & 25.0 & 8.1 \\
\hline Mexico & 20.0 & 3.0 \\
\hline Nicaragua & 31.2 & 10.4 \\
\hline Panama & 21.4 & 9.3 \\
\hline Paraguay & 10.0 & 5.7 \\
\hline Peru & 26.7 & 2.8 \\
\hline Dominican Republic & 17.6 & 11.3 \\
\hline Uruguay & 30.0 & n.a. \\
\hline Venezuela & 18.5 & 7.2 \\
\hline \multicolumn{3}{|c|}{ Source International IDEA (2007) and Llanos and Sample (2008). } \\
\hline
\end{tabular}

that developed a specific agenda to incorporate women in this sphere: Costa Rica (37.5 per cent), Chile (36.4 per cent), Ecuador (32 per cent) and Nicaragua (31.2 per cent). The counterpoint is countries like Venezuela (18.5 per cent), Dominican Republic (17.6 per cent), El Salvador (15.4 per cent), Brazil (14.3 per cent) and Paraguay (10 per cent), where the proportion of women ministers is still very low (Llanos and Sample 2008: 18). There is an inverse relationship between the proportion of women and position in the hierarchy: the higher the position in the hierarchy, the more unlikely it is to find women occupying these positions. In situations where executive spheres are reached by elections and where there is no quota system or affirmative action policy, there are fewer women still. As Table 2 shows, even in countries where women's participation reaches a two-digit number, as in Chile, Dominican Republic and Nicaragua, it is still very low.
This low participation of women in formal political arenas does not mean that women have been excluded from political action, or more broadly from political participation. Many studies have shown the intensity and amplitude of women's participation, especially in social movements. Sonia Alvarez (1994) refers to the democratisation process that happened in many Latin American countries (like Chile, Brazil, Argentina, Paraguay, Uruguay, Bolivia, Peru) in the 1980s, and emphasises the importance of women's participation in this process. Alvarez suggests that it was women who led protests against human rights violations, and they were the ones who came with creative solutions to community necessities when the State neglected them. They also played important roles in strengthening the Trades Union movement and in the struggle for land rights. It was Afro-Brazilian women who helped create a growing movement on Black consciousness and anti-racism; it was the lesbians that joined homosexuals against 
homophobia; it was academic women who held guns against the military regime and who joined opposing parties. However, all this participation by women did not consist of real possibilities to access political power.

In many Latin American countries, the muchdesired democracy that came after decades of military dictatorship left out the female electorate. The promises of democratic equality did not come true. In all so-called democratic societies, women have had to struggle hard to have access to the same rights as any male citizen, like equal salaries, promotion opportunities, the right to physical integrity, the right to work. That it has proven so difficult for women to get elected brings into question the democratic commitment of these societies, as well as the normative discourse of equality that is present in most constitutional texts, where the formal inclusion of women is explicitly mentioned. Many theoretical works on democracy point to women's inclusion as the basic condition that defines the democratic face of a society (Dall 1993; Bobbio 2000).

Implementing affirmative action, such as quota systems, can be a way to construct a truly democratic society that guarantees equal participation of men and women.

\section{Quotas in Latin America}

Argentina was the first Latin American country to establish a quota system through altering the Election Code, in 1961. Known as 'Ley de Cupos', this law stated that 30 per cent of all candidates on party lists for the national elections should be women. The law was the result of Argentinean women's struggle in a process that started during military dictatorship. The women who came to be known as the 'Mothers and Grandmothers from the Plaza de Mayo' were the first ones to go public and expose the military dictatorship's atrocities and also the first ones to ask for a democratic state. At the same time, a vibrant women's movement developed, connected to movements that resisted military dictatorship. In the late 1980 s, there was an intense effort to implement a quota policy, led by feminists with the help of women activists within the political parties.

In the beginning, taking their example from the European countries, women tried to negotiate with major parties to introduce quotas on their agendas. As the parties responded negatively, women came with a new strategy: to influence the national electoral code, with the aim of making it mandatory for parties to include more women on their lists. In 1990, the Political Feminists Network was created, bringing together women in 15 political parties. Their motto was 'with a few women in politics, women change; with a lot of women in politics, politics change'. This network became the entity that struggled for the quota law to be approved (Marx et al. 2007). In November 1991, the law was passed, and in March 1993, the law became a Decree that defined more explicitly the mechanism for the quota. By 1994, however, it had become clear that even those parties that were abiding by the law were putting women in positions on the lists where they had no possibility of being elected. This gave rise to a change in the 'Ley de Cupos', which established that women must be positioned on the lists in offices where there were real possibilities of election - one woman to every three positions on the list - and if this law was not followed the party couldn't subscribe its list and would be out of the electoral process. Conflicts emerged as parties persistently placed women in third place, and feminists took out lawsuits to challenge them. As a result, further legislation was passed in 2000 to clarify that: (1) the electoral quota applies to all vacancies for political office; (2) the 30 per cent of women candidates is a minimal percentage; (3) the quota is only considered as fulfilled when applied to the number of offices that each party organisation renews in the corresponding election. Despite these difficulties, the quota law in Argentina guaranteed a significant boost in women's presence in the representative system. Between 1991 and today, the percentage of women in politics has risen from 5.9 per cent to 39.6 per cent (Marx et al. 2007).

The Argentinean experience has been an example for those seeking to implement quotas in other Latin American countries. However, it was the Platform for Action that came out of the Fourth World Conference on Women, held in Beijing in 1995, which provided the impetus for national governments to begin to approve affirmative action mechanisms. Less than five years after the conference in Beijing, ten countries in Latin America had adopted the quota system. Yet despite the fact that most of them established a 
Table 3 Quotas and electoral systems in Latin America

\begin{tabular}{|c|c|c|c|c|c|c|}
\hline Country & $\begin{array}{l}\text { Year when } \\
\text { quota was } \\
\text { established }\end{array}$ & $\begin{array}{l}\text { Women's } \\
\text { percentage } \\
\text { before the } \\
\text { quota }\end{array}$ & $\begin{array}{l}\text { Women's } \\
\text { percentage } \\
\text { nowadays }\end{array}$ & $\begin{array}{l}\text { Minimal } \\
\text { quota } \\
\text { according } \\
\text { to the law }\end{array}$ & $\begin{array}{l}\text { Pre-established } \\
\text { office on the } \\
\text { list }\end{array}$ & $\begin{array}{l}\text { Kind of } \\
\text { list }\end{array}$ \\
\hline Argentina & 1991 & $\begin{array}{l}\text { Parliament } 6.0 \\
\text { Senate } 3.0\end{array}$ & $\begin{array}{l}38.3 \\
38.9\end{array}$ & 30 & Yes & Closed \\
\hline Paraguay & 1996 & $\begin{array}{l}\text { Parliament } 3.0 \\
\text { Senate } 11.0\end{array}$ & $\begin{array}{l}10.0 \\
8.9\end{array}$ & 20 & Yes & Closed \\
\hline Mexico & 1996 & $\begin{array}{l}\text { Parliament } 17.0 \\
\text { Senate } 15.0\end{array}$ & $\begin{array}{l}22.6 \\
17.2\end{array}$ & 30 & No & Closed \\
\hline Bolivia & 1997 & $\begin{array}{l}\text { Parliament } 11.0 \\
\text { Senate } 4.0\end{array}$ & $\begin{array}{l}16.9 \\
3.7\end{array}$ & 30 & Yes & Closed \\
\hline Brazil & 1997 & $\begin{array}{l}\text { Parliament } 6.4 \\
\text { Senate } 6.3\end{array}$ & $\begin{array}{l}8.8 \\
12.3\end{array}$ & 30 & No & Open \\
\hline Costa Rica & 1997 & Uniparliamental 14.0 & 36.8 & 40 & Yes & Closed \\
\hline Dominican Republic & 1997 & Parliament 12.0 & 19.7 & 25 & No & Closed \\
\hline Ecuador & 1997 & Uniparliamental 4.0 & 26.0 & 30 & Yes & Open \\
\hline Panama & 1997 & Uniparliamental 8.0 & 15.3 & 30 & No & Open \\
\hline Peru & 1997 & Uniparliamental 11.0 & 29.2 & 25 & No & Open \\
\hline Venezuela & 1997 & Unicameral & 18.6 & 30 & No & Closed \\
\hline
\end{tabular}

Source Veneziani (2006); International IDEA (2007); Llanos and Sample (2008).

30 per cent quota, and all have in common the active engagement of feminist activists in putting forward proposals, building alliances and persuading political parties, the diversity of experience has been surprising.

In the post-Beijing context, one of the first countries to establish the quota system was Costa Rica. Today, it is one of the most successful experiences in Latin America. The struggle to implement the quota system in Costa Rica started in 1984, close after the ratification of the Convention on the Elimination of All Forms of Discrimination against Women (CEDAW). As a result of pressure on the part of women's movements, some parties started to create internal mechanisms to promote and guarantee women's effective participation in political office and in electoral lists. Despite all this mobilisation, it took until November 1996 for the law establishing a quota system to be passed. The law required parties to assure 40 per cent of women's participation not only in the parties' structure, but also in candidacies for public election (Montanho 2007). Just like the quota law in Argentina, the Costa Rican law had to undergo some modifications to incorporate sanctions for parties that did not abide by it, whether by not fulfilling the 40 per cent or not positioning women in offices with real possibilities to be elected. In the first election after the law, in 1998, it was possible to see that even the parties that fulfilled the quotas put forward women with scarce possibilities of election. As a result, just two more women were elected as compared with the elections in 1994 (Perez 2008). In 1999, as a response to demands from the Women's National Institute, the Supreme Court established that women should constitute 40 per cent of the list of candidates, in eligible positions, and included mechanisms to guarantee that the law would be respected. Significant among these measures were the requirement that public campaign financing guaranteed equal access to party resources for all candidates, and the prerogative given to the electoral tribunal to refuse to register parties who 
did not comply with the quota law. More recently, in 2007, Costa Rica's national gender equality policy included, among its main issues, the need to enhance women's participation in politics, setting out a goal to have equal political participation in all decision-making spheres by 2017 (Montanho 2007).

At the same time as Costa Rica and Argentina began to see changes in the numbers of women entering political office as a result of quota systems, Ecuador and Peru began to implement quotas. Although the outcomes were less marked, these experiences are important because of the kind of mechanisms that were used. In 1997, Ecuador had established a 20 per cent quota, but it did not produce much in the way of results. In 2000, due to women's mobilisation, the 'Election Law' or 'Political Participation Law' was changed, establishing a 30 per cent quota and a gradual increase of 5 per cent in every election until the balance of 50 per cent is reached. All this mobilisation was based on Article 102 from Ecuador's new Constitution, established in June 1998, which says that 'the State will promote and guarantee the equal participation of women and men as candidates in popular election processes, in public field's directional and decision spheres, in justice's management, control organisms and political parties' (Government of Ecuador 1998).

In Peru, the Congress of the Republic approved the quota law in 1997, establishing a 25 per cent share in municipal elections and in the National Congress. Article 10 of the Municipal Election Law establishes that the candidate's list must be presented in a single document, in which the position of these candidates is made explicit, and in which there is a 25 per cent minimum of men or of women. In December 2000, this minimum quota increased to 30 per cent of men or women (Massolo 2007). Alejandra Massolo's 2007 study of women's political participation in local spheres in Latin America, points out that a fundamental element in Peru's success in the quotas system, despite an open list and the weakness of sanction mechanisms, was the action of four institutions:

The Manuela Ramos Movement, Social Communicators Association (CALANDRIA), Social Studies and Publishing Centre (CESIP) and the Centre of Studies to Development and Participation (CEDEP). These institutions outlined a women's political promotion programme, called PROMUJER, which was responsible for an intensive conscientisation programme to make women more aware about politics and to prepare women candidates politically.

Other significant experiences (not so much because of their success, but because these examples show the kinds of problems that can arise) are those of Mexico, Venezuela and Brazil. In Mexico, alliances between feminist activists in different political parties, such as that of the 'Grupo Plural' (Plural Group) were important in seeking mechanisms to guarantee higher levels of female political representation (Montanho 2007). The quotas law in Mexico was established in 1996 after a mobilisation process that started in 1993, with modifications in the Federal Code of Electoral Institutions and Procedures (COFIPE). It established that the parties must promote a greater female participation in political life. Despite its broad nature, this legislation produced an impact in the 1994 elections, when the percentage of women went from 8.4 to 13.8 in the Parliament and from 4.6 to 13.3 in the Senate (Reynoso and D'Angelo 2004: 5). In 1996, COFIPE was altered again to add a paragraph stipulating that, 'National Political Parties will take into account in their statute that candidacies to Parliament and Senate will not exceed a percentage of $70 \%$ to the same gender' (Reynoso and D'Angelo 2004: 6). In 2002, there was another attempt to make the quota law more effective by producing another modification in COFIPE, which established a mechanism for assuring gender balance in the list, and for punishing noncompliance. Despite these changes, the electoral legislation left a number of gaps. It did not define which kind of candidacies the quotas should be applied to, and as a result, parties put women as surrogates. As a result, the quota policy did not have the expected results, as can be seen from Table 3 (Reynoso and D'Angelo 2004).

Venezuela's experience also deserves mention. In 1997, it was made mandatory that political parties and electorates included a minimum of 30 per cent of women candidates in electoral lists. In 1998, at the time of the first election after this law was implemented, the quotas system was considered unconstitutional by the Electoral National Council, as it was deemed contrary to the equality principles established in the Venezuelan Constitution. Later, the Supreme 
Court supported this decision. In 1999, the new Constitution established for the first time a clear and explicit principle of equality, making clear the difference between formal equality and effective, real equality. The new Constitution also gives power to the executive, judiciary and legislative to implement positive actions, whenever they are needed in order to guarantee real and effective equality (Prince 2008). In 2005, after a great feminist movement struggle, based on claims using the equality text that is in the Bolivarian Constitution, a new resolution was passed establishing equality and balance in parties' lists. Because this law is still very frail and there is no system that can hold its non-implementation to account, it has done little to expand Venezuelan women's participation in politics.

The Brazilian experience with quotas is the least successful in the continent. Despite gaining political citizenship in 1934 and constituting the majority of Brazil's electorate, Brazilian women have not managed to be real citizens, and exercise not only the prerogative of voting, but also that of being elected. Women occupy less than 10 per cent of the electable offices in the country, ranking close to the bottom of the international register (Ballington 2007). Brazil's quota law was passed in 1995. It established that a minimum of 20 per cent of a party's candidates should be women. Applied in the 1996 elections, it was not enough to alter the picture of Brazilian women's political exclusion. It was succeeded, in 1997, by a law that made it mandatory to have a minimum of 25 per cent of women candidates in the 1998 elections and an increase to 30 per cent in the following election. Today the law 'assures' 30 per cent of the candidates presented by parties at municipal, state and federal levels should be women. It is a law that is still to find its force, however.

Before the quota law was passed, Brazil had already experienced a range of other kinds of political quotas. In 1991, the Workers' Party (PT) passed a quota assuring a minimum of 30 per cent of each gender in the directorate of the party. In 1993, the Unified Workers' Central (CUT) did the same, establishing no fewer than 30 per cent and no more than 70 per cent of people from each gender. Despite quotas, the increase in women's participation has been minimal. There is no sanction, so there is no penalty for parties which do not comply.
Transforming this law has been a major challenge for the women's movement. In September 2009, a new electoral law was approved in the National Congress, which represents some small gains for the women's movement. Women had advocated for 30 per cent of the public funds that are given to parties to be spent on the political education of women; the new law proposed 5 per cent, and that each party which did not do this would be obliged to spend an additional 2.5 per cent in the following year, but no specific penalties were defined for those which did not comply with this law. In addition, the law stipulates that at least 10 per cent of the time available to political parties for party political broadcasts on radio and TV should be used to promote the participation of women in politics (the original demand of the women's movement was 20 per cent). Lastly, the new law maintains the quota of 30 per cent but apart from emphasising that this is an obligation, it does not establish any kind of punishment for parties which do not comply with the law.

The difficulties that women face getting their demands taken up by the National Congress is a reflection of their political force in this space, where they occupy less than 10 per cent of the seats. Women are absent at the tables where negotiations take place, and experience many constraints to political effectiveness. Their submersion in a sea of male and party interests makes it difficult to imagine them playing a more active role in modifying or reforming laws. There is an evident paradox between the force of political mobilisation of the Brazilian feminist movement and their real representation in the spheres of political implementation and deliberation. Women's absence in power structures in this country also reflects in the possibilities they have for intervention, in their capacity for democratic transformation, and in their difficulty in constituting themselves as political actors able to make demands (Costa 2008).

\section{Quotas: a pathway to equality?}

A superficial analysis of the outcomes of the adoption of quotas in Latin America can lead to the impression that this experience has not been able to significantly alter women's participation in power structures. We can see that except in the cases of Argentina and Costa Rica, the indices for women's presence in formal politics 
are still very low, with only small increases in the wake of the implementation of quota systems. Yet to regard this as evidence that quotas are not pathways of women's political empowerment is to miss the important point that a quota system on its own is not enough to bring about the kind of changes that are needed for women to achieve a greater share of representation in political institutions. Laws by themselves do not assure greater political representation. As Dahlerup (2003) notes, to work effectively, quota systems need to be complemented with programmes that build the capacity of women candidates and women in elected office.

Many studies have also demonstrated that the success or failure of quota systems is directly related to the characteristics of the country's electoral system, to the degree of explicitness in setting out the rules that support measures to increase the representation of women including elements of design that make it more difficult to relegate women candidates to unelectable positions, to the lowest places on the list or to positions as surrogates - and to the participation of civil society in monitoring implementation and the application of rules, including sanctions (Veneziani 2006). Some of the countries where quotas have been most successful, among them Argentina, use a closed list system, with candidates listed in priority order. The electorate votes for the list in its totality, with no possibility of altering its order. If the quota law defines the position women should occupy in this list, the possibility of success is guaranteed. If the legislation does not mention anything about the position women should be put in the list, parties tend to put women at the end of the list, decreasing their possibility of being elected. According to Jones (2000), to make a closed list system effective, the laws that refer to the quota system must include a positioning determination to be occupied by women on the list positioning mandate. The legislation establishes mechanisms to make it mandatory, as well as to make it possible to hold parties to account for non-compliance. This is what happens in Argentina, Bolivia and Paraguay, where the law determines that if the party does not fulfil the quotas, it cannot register its candidates. In Mexico, Ecuador, Peru, Brazil and Panama, the legislation does not specify the position in which women should be on the list, nor does it establish mechanisms to hold parties to account. This kind of quota policy tends to fail in its goal to increase the presence of women. If there is no express determination to include women in positions on the lists, the whole point of the quota tends to be lost given that the party's decisions are generally in men's hands.

\section{Conclusion}

The experience of the quota system in Latin America suggests a number of broader lessons, with relevance to other countries where efforts are being made to expand the numbers of women in political office. The first is that quota systems alone are not sufficient to create the conditions for women to empower themselves politically; quotas are not automatic pathways of political empowerment for women. But when quotas are complemented with public policies to promote equality that can create deeper transformations in the patriarchal structure in society, with the perspective of expanding democracy, then they can serve as a channel for change.

The principal lesson from the experience of quota systems in Latin America is the need for a strong women's movement that can make effective demands. What we see in these diverse experiences is the importance of pressure that women's movements have brought to bear, their role in developing proposals, establishing alliances and mobilising the political parties. It is within the political parties that the process of convincing needs to be the most intense. It was only after the activism of feminists within the political parties that the quota system in Argentina and Costa Rica was approved. To have the party as an ally is one of the most indispensable pathways in the process of changing laws. Another lesson emerging from the Latin American experience relates to how the quota system is applied. For quotas to work, there needs to be a clear set of rules and procedures, which cover a range of mechanisms for legal punishment and restrictions for those who do not comply with the provisions made within the law. Experience shows that an electoral system with closed lists, alternating positions in the list according to sex, and a comprehensive system of incentives and punishment may contribute favourably to the success of the quota system. Ultimately, women's right to equal representation in formal political systems needs to be recognised as a fundamental part of the project of democratisation that, in 
Latin America, remains incomplete as a result of the continued exclusion of women from politics.

In Brazil, where the legacy of the military dictatorship has led to resistance on the part of feminists to get involved in party structures, currently they only have a very limited presence in most political parties, this negotiation is more difficult. Even in the parties which have a significant number of feminist activists - such as the Communist Party or the Workers' Party there is a tendency among these women to preserve their party agreements or the political line defined by the male majority, in detriment of feminist demands. This positioning became explicit in the vote for political reform in August 2008 in the National Congress, when some deputies, committed to the demands presented by the women's movement for a closed list, party

\section{References}

Alvarez, S. (1994) 'La (trans)formación del (los) Feminismo(s) y la Política de Género en la Democratización del Brasil' ['The Transformation of Feminisms and the Politics of Gender in the Democratization of Brazil'], in M. Leon (ed.), Mujeres y Participación Politica. Avances y Desafios en América Latina [Women and Political Participation: Advances and Challenges in Latin America], Bogotá: Tercer Mundo

Ballington, J. (2007) 'Implementando Medidas Especiais: Tendências Globais' ['Implementing Special Measures: Global Trends'], Seminário Trilhas do Poder das Mulheres. Experiencias Internacionais em Ações Afirmativas [Seminar on Women's Pathways of Power: International Experiences in Affirmative Action], Brasília: Congresso Nacional

Bobbio, N. (2000) Teoria Geral da Política. Filosofia Política e as Lições dos Clássicos [The General Theory of Politics: Political Philosophy and Lessons from the Classics], Rio de Janeiro: Campus

Costa, A.A.A. (2008) 'Construindo um Novo Contrato: o Feminismo e a Democracia Paritária no Contexto da Reforma Política de 2007' ['Constructing a New Contract: Women and Party Political Democracy in the Context of the Political Reform of 2007'], paper presented at the II Seminário Internacional Enfoques Feministas e o Século XXI: Feminismo e Universidade na América Latina [2nd International Seminar Focusing on Feminists in the 21 st Century: Feminism and the University loyalty, resources for women candidates and so on, voted in plenary according to agreements made with their parties, forgetting totally the agreements they had made with the women's movement. One of the paradoxes of feminist activism within political parties is exactly the subordination of women to the authoritarian and patriarchal practices established in the name of party discipline. We know that quotas by themselves are not sufficient to change the patriarchal structures of society. What is necessary is a broader process of changing relations of gender in the patriarchal structures of the political parties, and of society, changing the family, the school, and women's lives. But despite this, the entry of women into formal structures of power is and should be a question of democracy. Women have a right to this place of power.

in Latin América], Belo Horizonte:

Universidade Federal de Minas Gerais

Costa, A.A.A. (1998) As Donas no Poder. Mulhere Política na Bahia [Mistresses of Power: Women and Politics in Bahia], Salvador: Assembléia Legislativa da Bahia/NEIM-UFBa Coleção Bahianas

Dahlerup, D. (2003) 'Quotas are Changing the History of Women', paper presented at the conference 'The Implementation of Quotas: African Experiences', Pretoria, 11-13 November

Dall, R. (1993) La Democracia y sus Críticos [Democracy and Its Critics], Barcelona: Paidós

Government of Ecuador (1998) Constitution of the Republic of Ecuador, approved 5 June 1998, www.ecuanex.net.ec/constitucion (accessed 2 January 2009)

International IDEA (2007) Political and Electoral Reform in Latin America 1978-2007, Stockholm: International Institute for Democracy and Electoral Assistance

Jones, M.P. (2000) 'El Sistema de Cuotas y la Elección de las Mujeres en América Latina: El Papel Fundamental del Sistema Electoral' ['The System of Quotas in the Election of Women in Latin America: The Fundamental Role of the Electoral System'], in Impacto de los Sistemas Electorales en La Representaciòn Politica de las Mujeres [The Impact of Electoral Systems on the Political Representation of Women], www.celem.org/ prog_europeos/demo_paritaria2000/pdfs/ capitulo01.pdf (accessed 17 December 2009) 
Llanos, B. and Sample, K. (2008) 30 Anos de Democracia: En la Cresta de la Ola Participación Política de La Mujer en América Latina 30 Years of Democracy: Riding the Wave? Women's Political Participation in Latin America], Stockholm: International Institute for Democracy and Electoral Assistance (IDEA)

Marx, J.; Borner, J. and Caminotti, M. (2007) 'Cuotas de Género y Acceso Femenino al Parlamento: Los Casos de Argentina y Brasil en Perspectiva Comparada' ['Gender Quotas and Women's Access to Parliament: The Cases of Argentina and Brazil in Comparative Perspective'], http://pnud.mediagroup.com.ar/ boletines/2007/42/Notas/IMG/Cuotas_de_ genero_en_Argentina_y_Brasil.pdf (accessed 2 January 2009)

Massolo, A. (2007) Participación Política de las Mujeres em el en el Ámbito Local en América Latina [The Political Participation of Women at the Local Level in Latin America], Santo Domingo, República Dominicana: Instituto Internacional de Investigaciones y Capacitación de las Naciones Unidas para la Promoción de la Mujer

Montanho, S. (2007) 'A Contribuição das Mulheres para a Igualdade na América Latina e no Caribe' ['The Contribution of Women to Equality in Latin America and the Caribbean'], paper presented at the 10th Regional Conference on Women in Latin America and the Caribbean, 6-9 August, Quito, Ecuador

Perez, N. (2008) 'La Cuota Mínima del 40\% de Participación Política de las Mujeres en Costa Rica: A Diez Años de su Implementación' ['The Minimum Quota of 40\% of Women's Political Participation in Costa Rica: Ten
Years of its Implementation'], presentation at Seminario Internacional una Década de Cuota Femenina en America Latina. Balance y Perspectivas para la Participacion Politica de la Mujer, [International Seminar of a Decade of the Women's Quota in Latin America: Balance and Perspectives for the Political Representation of Women], 13-15 October, Santo Domingo

Prince, E.G. (2008) 'Analisis de La Situación de la Participación Política de las Mujeres en Venezuela' ['Situation Analysis of Women's Political Participation in Venezuela'], paper presented at Seminario Violencia, Salud y Derechos Políticos con Perspectiva de Género, 31 July, Caracas, Fundação Frederich Albert Reynoso, D. and D’Angelo, N. (2004) 'Leyes de Cuotas y Elección de Mujeres en México. Contribuyen a Disminuir la Brecha entre Elegir y ser Elegida?' ['Quota Laws and the Election of Women in Mexico. Do they Contribute to the Gap between Electing and being Elected?'], paper presented at the XVI Congreso de la Sociedad Mexicana de Estudios Electorales [16th Congress of the Mexican Society of Electoral Studies], 18-19 November, Torreón, Coahuila, www.quotaproject.org/ Conference_papers/CUOTAS_SOMEE_2004. pdf em 03/01/2009 (accessed 2 January 2009)

Veneziani, M. (2006) Experiencias Latinoamericanas: Mecanismos de Cuotas a Favor de la Participación Política de las Mujeres [Latin American Experiences: Quota Mechanisms in Favour of the Political Participation of Women], Dominican Republic: UN International Research and Training Institute for the Advancement of Women (INSTRAW) 